\section{The Camford Visitation}

By H. G. Wells. Pp. 76. (London: Methuen and Co., Ltd., 1937.) $2 s$.

MR. WELLS'S address as president of the Educa11 cational Science Section of the British Asso. ciation last year dealt with certain aspects of education in the schools only. In his latest story, with its cover of dark and light blue, he deals with university education and its place in society. The story begins with an amusing sketch of a dyedin-the-wool scholar, the master of Holy Innocents College, a preserver of culture, of true scholarship, born to appreciate without ever creating. His breakfast oration has got to the stage of denouncing "the dictatorship of the half-educated. We are being endowed, Sir, and told what to know and teach, by the unholy wealth of ironmongers and the overblown profits of syndicated shop-keepers." Then enters the visitant as a voice, an unseen presence, asking: "Half-educated? Now how can you measure education and divide it into halves and quarters? What do you mean by education ?..." For the rest of the story the visitant subjects human life, and in particular its treatment by the University of Camford, to a sympathetic but quite unsparing scrutiny. The general thesis is an appeal to the universities to play a part in "so heroic an ordering of knowledge, so valiant a beating out of opinions, such a refreshment of teaching and such an organization of brains as will constitute a real and living world university, head, eyes and purpose for Man".

In the development of the thesis many topics are reviewed or touched, with Wellsian incisiveness and ironic humour-the claim that the humanities are wisdom and that science is not, the pseudo-scientific explanations of psycho-analysis, the fashionable philosophy-cum-politics-cum-religion called dialectical materialism. "To see a novel proposition pass through a Marxist gathering is like watching a breeze across a field of ripe corn. It passes, and the serried minds return to their upstanding integrity." Mr. Wells is here as stimulating, provocative and entertaining as ever, but the visitant treats university science teaching more kindly than we should have expected.

Out of my Life and Work

By Auguste Forel. Translated by Bernard Miall. Pp. $352+8$ plates. (London: George Allen and Unwin, Ltd., 1937.) 16s. net.

THIS volume of memoirs deals with a full and varied life. Prof. Forel became a psychiatrist by profession and simultaneously was one of the leading European myrmeologists. A narrow and isolated early upbringing led him to take refuge in Nature around him and, before he was eight years old, he had become interested in ant life. Forel was destined for medicine, and he seems to have prosecuted his studies in this subject side by side with those on ants. Failure to pass the examinations at Zurich led to his transference to Vienna. Here he graduated and secured his first post, which was under Prof. Gudden in Munich.

Forel had been working for some time at his "Ants of Switzerland" and in 1875 this treatise received the
Thore Prize of the Paris Academy of Sciences. In 1879 he became assistant physician at the Burghölzli Asylum, overlooking Lake Zurich. Here he remained for nearly twenty years, becoming its director, and also professor in the University of Zurich. His energies were devoted to research, teaching and treatment in connexion with insanity. His earlier studies on the brains of normal individuals and of mental deficients were followed by his development and application of hypnotic suggestion as a method of treatment. He tells much of his life at Burghölzli, of its trials, misunderstandings and successes; of his travels to other lands in order to further his studies of ants; of his politics and of his efforts as an uncompromising opponent of alcoholism ; and of his life in retirement and its retrospection. These memories are written in a frank, unpretentious style, and reflect their author's efforts in recording the events of his life in their proper perspective. The work of translation has been ably done by $\mathbf{M r}$. Bernard Miall.

\section{The Chromosomes}

By M. J. D. White. (Methuen's Monographs on Biological Subjects.) Pp. viii +128. (London : Methuen and Co., Ltd., 1937.) 3s. 6d. net.

7 HIS competent book of 128 pages provides a guide to recent discoveries in eytology. It describes the phenomena of mitosis and meiosis, considers chromosomes in relation to evolution and does not shrink from invading the realms of advanced cytological theory. The book contains a curious mixture of well-written, easily understood remarks on advanced work, combined with involved descrip. tions of more elementary material. This is probably due to the author's endeavour to cover as much of the ground as possible in a small book.

A glossary is provided, but the definitions are not always strictly specific. The book is to be recommended to those who require a summary of the modern theories and discoveries of cytology and will undertake further reading of authorities in the excellent bibliography.

F. W. S.

Life and Death:

the Autobiography of a Surgeon. By Prof. Andrea Majocchi. Translated by H. J. Stenning. Pp. 343. (London: George Allen and Unwin, Ltd., 1937.) 10s. 6d. net.

THE author of this temperamental book, which is obviously intended as much for the layman as for the medical reader, is professor of surgery at Milan and consultant to the Ospedale Maggiore. In addition to a short history of this hospital, the work contains a vivid description of the author's practice in the Obstetrical Department, his visits to the surgical clinics of Switzerland, the United States, Paris and Berlin, his War service at the Front and especially the treatment of wounds of the abdomen, brain and spinal cord and the "roses and thorns" of a surgeon's career. Chapters are also devoted to the nursing profession as seen through Italian spectacles, and a satirical account of a medical congress. 